\title{
Rasio Keuangan Sebagai Penentu Kondisi Kesulitan Keuangan Pada Perusahaan Sektor Transportasi Pada Bursa Efek Indonesia
}

\author{
REFNI SUKMADEWI \\ Sekolah Tinggi Ilmu Ekonomi Persada Bunda \\ Jl. Diponegoro No. 42 Pekanbaru \\ E-mail : Soekma_dhewi@yahoo.co.id
}

\begin{abstract}
This research aims at providing empirical evidance on factors that affect firms financial distress. This research examines the role of financial ratios at 2015 in predicting the occurance of financial distress at firm in sector transportation listed at Bursa Efek Jakarta. Discriminant analysis used to test the ability of financial ratio to predict financial distress and construct financial distress prediction model by using stepwise procedure. Variabel indicator are financial ratios. The result shows that there are three ratios different and significantly effect financial distress prediction model. The ratios are, Working Capital/Total Asset Current Asset/Total Asset, dan Equity/Total Aset. The classificaton results based on the cut-off-Z Score values able to predict firms financial distress in sector transportation at the accuracy rate of $100 \%$. The accuracy rate of model shows that discriminant model is accurate in measuring financial distress at firms in sector transportation.
\end{abstract}

Keywords: Financial Ratios, Financial Distress

Kondisi ekonomi di Indonesia terus berubah dari satu periode ke periode lainnya. Setiap tahun, Indonesia mengalami kejadian ekonomi, yang berpengaruh pada situasi ekonomi global maupun regional. Pertumbuhan ekonomi Indonesia pada 2015 sebesar 4,79 persen, merupakan pertumbuhan ekonomi yang terendah selama 6 tahun dari tahun 2009 menurut Badan Pusat Statistik. Turunnya pertumbuhan ekonomi kita dibanding tahun sebelumnya salah satunya adalah penurunan kinerja ekspor seiring anjloknya harga komoditas dan lambannya eksekusi belanja pemerintah. Sektor industri merupakan motor penggerak bagi pertumbuhan perekonomian menuju keadaan yang lebih baik. Namun dalam beberapa tahun, kinerja sektor industri tanah air turun. Hal ini disebabkan kenaikan harga bahan bakar minyak yang menyebabkan menurunnya daya beli masyarakat.

Industri jasa memiliki
potensi besar untuk meningkatan
pertumbuhan ekonomi Indonesia karena
dapat berkontribusi terhadap peningkatan
Produk Domestik Bruto Nasional,

penciptaan lapangan kerja. Industri jasa masih berpeluang tumbuh di Indonesia. Apabila dikelola dengan baik potensi kontribusinya sangat besar bagi perekonomian Indonesia. Sektor industri jasa berkontribusi meningkatkan Produk Domestik Bruto nasional dari 45 persen di tahun 2010 menjadi 55 persen di tahun 2012. Selain itu mampu mencipatkan 21,7 juta lapangan pekerjaan dalam kurun waktu 2000-2010. Industri jasa mampu mengurangi angka kemiskinan di Indonesia.

Sektor jasa mampu menjadi sumber utama pertumbuhan ekonomi Indonesia melalui berbagai industri jasa seperti pariwisata, logistik, dan transportasi. Kendati begitu, masih terdapat sejumlah kendala dalam pengembangan sektor industri jasa ini. Salah satunya masih lemahnya daya saing pelaku industri jasa di Indonesia karena adanya kebijakan dan regulasi yang membatasi kesempatan pertumbuhan industri jasa. Kebijakan pemerintah saat ini semakin mendukung pertumbuhan sektor jasa. Dengan kebijakan Indonesia yang telah menyepakati Asean 
Framework Agreement on Services (AFAS) membuka peluang sektor jasa domestik untuk berkembang tidak hanya di dalam negeri, namun juga di tingkat regional tanpa adanya dikriminasi maupun hambatan.

Industri transportasi merupakan salah satu infrastruktur pendukung pertumbuhan ekonomi yang sangat strategis. Peranan perusahaan transportasi sangat penting untuk saling menghubungkan daerah sumber bahan baku, daerah produksi, daerah pemasaran dan daerah pemukiman sebagai tempat tinggal konsumen. Pengangkutan berfungsi sebagai faktor penunjang dan perangsang pembangunan dan pemberi jasa bagi perkembangan ekonomi. Sebagai salah satu mesin pertumbuhan, sektor ini membutuhkan dukungan anggaran besar. Untuk itu dibutuhkan modal besar agar perusahaan dapat menjalankan kegiatan bisnisnya. Investor menjadi salah satu penyedia dana dalam kegiatan bisnis perusahaan.

Pertumbuhan industri transportasi tidak akan merata dikarenakan adanya saham yang memiliki eksposure yang kuat terhadap krisis ekonomi global. Subsektor transportasi laut diperkirakan masih sulit tumbuh. Melemahnya harga komoditi membuat transaksi perdagangan internasional masih akan rendah. Jasa angkutan laut masih didominasi oleh produk-produk komoditi dan migas yang paling terimbas perlambatan ekonomi global.

Prediksi terhadap perusahaan yang mengalami kesulitan keuangan merupakan suatu studi yang menarik. Analisis kesulitan keuangan sangat membantu dalam mengambil keputusan untuk melihat kemampuan perusahaan mengelola kasnya. Perusahaan secara tepat waktu diharapkan dapat memenuhi kewajiban membayar bunga, cicilan hutang, dan penyediaan modal kerja.

Penelitian akademis bisa menyediakan model untuk mencegah kesulitan keuangan yang sangat diperlukan di Indonesia. Keberadaan model diharapkan membantu perusahaan, investor, kreditor dan pihak lain untuk mengawasi kinerja keuangan perusahaan. Ada cara yang bisa menggambarkan kondisi keuangan perusahaan pada pasar di Indonesia dengan membuat model prediksi untuk memprediksi kemungkinan kesulitan keuangan perusahaan di Indonesia sebagai instrumen peringatan. Karena itu dibangun model berdasarkan rasio keuangan yang diharapkan dengan model tersebut adalah sebagai peringatan untuk memprediksi kesulitan keuangan perusahaan.

Altman memformulasikan model prediksi kesulitan keuangan dengan menggunakan lima rasio keuangan yang dikenal dengan Altman $\mathrm{Z}$ Score. Menggunakan analisis diskriminan linier dengan akurasi 95\% kasus kesulitan keuangan pada satu tahun sebelum kesulitan keuangan terjadi. Analisis diskriminan yang dipakai dalam formulasi $\mathrm{Z}$ Score umumnya dipakai untuk mengklasifikasikan sekumpulan observasi kedalam beberapa kelompok, biasanya variabel dependen yang akan diformulasikan bersifat kualitatif, seperti mengalami kesulitan keuangan atau tidak mengalami kesulitan keuangan.

Z-Score yang pertama kali dikembangkan untuk menentukan kesulitan keuangan dapat juga digunakan sebagai ukuran dari keseluruhan kinerja keuangan perusahaan. Hal yang menarik dari Z-Score adalah keandalannya sebagai alat analisis tanpa memperhatikan bagaimana ukuran perusahaan

\section{METODE}

Dalam penelitan ini akan membentuk model kesulitan keuangan pada perusahaan-perusahaan transportasi di Indonesia berdasarkan rasio-rasio keuangan, dengan menggunakan data laporan keuangan periode tahun 2015 sebagai penentu statusnya. Berdasarkan model yang terbentuk, diharapkan dapat menghasilkan nilai yang dapat memprediksi 
perusahaan-perusahaan transportasi dalam kategori mengalami kesulitan keuangan dan yang tidak mengalami kesulitan keuangan dalam kategori.

Dengan demikian, maka metode yang digunakan dalam penelitian ini adalah metode deskriptif dan eksploratif yang bertujuan untuk memberikan gambaran sistematis dan akurat mengenai fakta yang ditemukan pada perusahaan-perusahaan transportasi menggunakan data sekunder dari laporan tahunan di Bursa Efek Indonesia. Analisis deskriptif dilakukan untuk memperoleh kejelasan mengenai variabel yang akan diteliti. Analisis eksploratif berusaha untuk mecari ide-ide atau hubungan yang baru dan tidak menggunakan hipotesis.

Data berupa 13 rasio keuangan sebagai variabel independen. Variabel Dependen adalah adalah status keuangan perusahaan. Kesulitan keuangan secara teknis terjadi apabila kondisi perusahaan mempunyai nilai buku jumlah kewajiban melebihi jumlah nilai aset, sehingga nilai ekuitas menjadi negatif, maka perusahaan tersebut dalam kondisi mengalami kesulitan keuangan. Sebaliknya nilai perusahaan memiliki ekuitas positif maka perusahaan berada dalam kondisi tidak mengalami kesulitan keuangan. Dalam pengujian statistik, kedua status tersebut kemudian dikuantifikasi menjadi angka 0 untuk perusahaan yang tidak dalam kondisi kesulitan keuangan, dan angka 1 untuk perusahaan yang terkondisikan dalam mengalami kesulitan keuangan. Data di analisis menggunakan analisis diskriminan menggunakan bantuan program SPSS.

\section{HASIL}

Identifikasi rasio keuangan dilakukan dengan cara menguji kesamaan rata-rata kelompok yang dapat digunakan dengan 2 cara, yaitu Wilks' Lambda dan F Test. Besarnya angka Wilks' Lambda adalah antara angka 0 sampai angka 1 . Jika angka mendekati 0 , maka data cenderung berbeda sebaliknya jika angka mendekati 1 maka data cenderung sama. Ada empat variabel yang mempunyai angka signifikan yang mendekati
0 yaitu variabel X2 (Working Capital/Total Asset), variabel X8 (Net Income / Total Asset), X10 (Liability/Total Asset), dan X11 (Equity/Total Asset). Dengan demikian empat variabel tersebut merupakan faktor pembeda dalam memprediksi kesulitan keuangan .

Dalam uji $\mathrm{F}$ Test ini akan dilihat variabel independen mana saja yang berbeda secara signifikan menggunakan kriteria $\mathrm{F}$ test dengan ketentuan berikut ini: Jika signifikan $>0,05$, maka tidak akan ada perbedaan dalam kelompok dan Jika signifikan <0,05, maka ada perbedaan dalam kelompok

Ada empat variabel yang mempunyai angka signifikan lebih kecil dari 0,05 yaitu variabel X2 (Working Capital/Total Asset), variabel X8 (Net Income / Total Asset), X10 (Liability/Total Asset), dan X11 (Equity /Total Asset). Dengan demikian empat variabel tersebut merupakan faktor pembeda dalam memprediksi kesulitan keuangan.

Jika dilihat pengujian menggunakan kriteria Wilks' Lambda dan kiteria angka F terdapat kesamaan variabel-variabel independen yang dianggap signifikan. Setelah dilakukan uji rata-rata kelompok diatas, selanjutnya dari empat variabel yang dianggap signifikan ini, akan dilanjutkan dengan menguji signifikan perbedaan antara kedua kelompok dan mencari faktor-faktor pembeda yang mempengaruhi terbentuknya klasifikasi dua kelompok, yaitu kelompok yang yang mengalami kesulitan keuangan (0) dan kelompok yang tidak mengalami kesulitan keuangan (1) dengan menggunakan metode stepwise.

Model diskriminan dibentuk dengan menggunakan metode stepwise. Prosedur stepwise dilakukan untuk menentukan variabel-variabel independen mana yang efisien dalam membedakan perusahaan yang mengalami kesulitan keuangan atau yang tidak mengalami kesulitan keuangan perusahaan. Prosedur stepwise dimulai dengan memilih rasio keuangan yang dikeluarkan dari model.

Dari empat variabel independen 
yang dianggap signifikan menggunakan kriteria angka Wilks' Lambda dan angka $\mathrm{F}$ tadi, ada tiga variabel independen yang dianggap memiliki discriminating power paling tinggi, artinya yang paling membedakan diantara kelompok.

Dalam memilih variabel independen yang masuk dalam model diskriminan, sesuai aturan dalam metode stepwise ini maka hanya variabel yang mempunyai nilai Mahalanobis distance tinggi yang dimasukkan, lalu periksa apakah nilai signifikansi nya lebih kecil dari 0,05. Jika nilai signifikansi nya lebih kecil dari 0,05 maka variabel tersebut dimasukkan dalam model diskriminan.

Tiga variabel independen yang dimasukkan kedalam prosedur stepwise tadi dianggap paling signifikan. Dengan demikian dapat dikatakan bahwa variabel Working Capital / Total Asset (X2), variabel Equity/Asset (X11), dan variabel Current Asset/Current Liability (X3) membedakan kondisi perusahaan yang mengalami kesulitan keuangan atau yang tidak mengalami kesulitan keuangan pada perusahaan sektor transportasi.

Wilks' Lambda pada prinsipnya adalah jumlah varian diskriminan yang tidak bisa dijelaskan oleh perbedaan diantara kelompok-kelompok yang diteliti. Terjadi proses tahapan tiga kali sesuai dengan jumlah variabel bebas yang memenuhi persyaratan. Pada tahap pertama $11,9 \%$ varian tidak dapat dijelaskan oleh adanya perbedaan antar kelompok, Pada tahap kedua $8,1 \%$ varian tidak dapat dijelaskan oleh adanya perbedaan antar kelompok , Pada tahap ketiga 5,1\% varian tidak dapat dijelaskan oleh adanya perbedaan antar kelompok.

Penurunan angka Wilks' Lambda adalah baik untuk model diskriminan, karena varian yang tidak bisa dijelaskan semakin kecil. Angka signifikan untuk ketiga variabel sebesar 0,000 adalah lebih kecil dari 0,05. Karena ketiga variabel tersebut mempunyai nilai signifikan lebih kecil dari 0,05 maka variabel tersebut mempunyai perbedaan yang signifikan.

Aspek multivariate model dilaporkan dalam
Eigenvalues. Canonical correlation menunjukkan hubungan antara nilai diksriminan dengan kelompok. Nilai Canonical correlation yang baik adalah jika memiliki nilai $>0,50 \quad(50 \%)$. Nilai Canonical correlation sebsar 0,974 $(97,4 \%)$ menunjukkan hubungan yang tinggi karena memiliki nilai $>0,50(50 \%)$.

Stuctuce matrix menunjukkan adanya korelasi antara variabel-variabel independen dengan fungsi diskriminan yang terbentuk. Variabel X2 (Working Capital / Total Asset) paling erat hubungannya dengan fungsi diskriminan, diikuti oleh variabel X11 (Equity/Total Asset), dan X3 (Current Asset/Total Asset). Dari tabel structure matrix tadi dapat dilihat bahwa variabel yang diikutkan dalam proses analisis diskriminan adalah (yang tidak bertandakan huruf a) yaitu variabel X2 (Working Capital / Total Asset) paling erat hubungannya dengan fungsi diskriminan, diikuti oleh variabel X11 (Equity /Total Asset) dan X3 (Current Asset/ Total Asset).

Dari analisis menggunakan model diskriminan diperoleh model sebagai berikut:

$Z=-4,882+-7,198 \times 2+6,348 \times 3+3,574 \times 11$

Dimana:

$\mathrm{X} 2=$ Working Capital/Total Asset

$\mathrm{X} 3=$ Current Asset/Total Asset

$\mathrm{X} 11=$ Equity/TotalAset

Dari fungsi diskriminan yang diperoleh, dapat dilihat bahwa nilai rata-rata variabel yang paling dominan untuk memprediksi perbedaan kelompok perusahaan yang diprediksi mengalami kesulitan keuangan dan tidak mengalami kesulitan adalah variabel X3 (Current Asset/Total Asset.), karena memiliki koefisien tertinggi sebesar 6,348. Sedangkan rata-rata variabel yang paling lemah memprediksi kesulitan keuangan adalah variabel X2 (Working Capital/Total Asset), karena memiliki koefisien terendah sebesar -7,198.

Untuk masing-masing kelompok terdapat nilai rata-rata untuk nilai Z Score diskriminan yang disebut centroid. 
Terdapat dua kelompok diskriminan yaitu kelompok yang diprediksi mengalami kesulitan keuangan memiliki rata-rata 11,212 dan kelompok yang diprediksi tidak mengalami kesulitan keuangan memiliki rata-rata $-1,529$.

Keakuratan prediktif fungsi diskriminan dicapai dengan classification result. Sebelum mengembangkan classification result, terlebih dahulu menentukan cutting score.

Karena critical cutting score sebesar 9,683 maka prosedur untuk mengklasifikasikan perusahaan adalah: Z> 9,683; perusahaan yang dikategorikan mengalami kesulitan keuangan $\mathrm{Z}<9,683$; perusahaan yang dikategorikan tidak mengalami kesulitan keuangan

Selanjutnya dilakukan prosedur casewise statistic untuk mengevaluasi tingkat keberhasilan model diskriminan yang dihasilkan dalam mengidentifikasi kesulitan keuangan pada perusahaan sektor transportasi. Hasil prosedur casewise statistic berupa nilai Z Score dan hasil yang diperoleh berdasarkan nilai $\mathrm{Z}$ Score menggunakan model diskriminan.

Prediksi kesulitan keuangan ditentukan dengan melihat nilai equity perusahaan. Bila nilai equity positif maka dikategorikan perusahaan yang tidak mengalami kesulitan keuangan, sedangkan bila equity negatif maka dikategorikan perusahaan yang mengalami kesulitan keuangan. Berdasarkan nilai equity tersebut terdapat 3 perusahaan yang mengalami kesulitan keuangan yaitu PT Arpeni Pratama Ocean Line Tbk, PT ICTSI Jasa Prima Tbk, dan PT Steaddy Safe Tbk. Sedangkan 22 perusahaan lainnya tidak mengalami kesulitan keuangan. Dari prosedur casewise statistic dapat dilihat mana saja perusahaan yang memiliki nilai $Z>\quad 9,683$ yaitu perusahaan yang dikategorikan mengalami kesulitan keuangan dan perusahaan yang memiliki nilai $Z<9,683$ yaitu perusahaan yang dikategorikan tidak mengalami kesulitan keuangan. Ada dua perusahaan yang berada pada mengalami kesulitan keuangan dengan nilai $Z>9,683$ yaitu PT Arpeni Pratama Ocean Line Tbk, dan PT
Steaddy Safe Tbk. Nilai Z Score PT Arpeni Pratama Ocean Line Tbk sebesar 13,070, dan nilai Z Score PT Steaddy Safe Tbk sebesar 12,203. Sedangkan 23 perusahaan lainnya berada pada kondisi tidak mengalami kesulitan keuangan yang memiliki Z<9,683.

Dari 3 perusahaan yang awalnya diprediksi kesulitan keuangan dan 22 perusahaan yang diprediksi tidak kesulitan keuangan. Setelah menggunakan model diskriminan dengan didasarkan pada nilai cut off score yang telah ditentukan, terdapat 3 perusahaan kesulitan keuangan dan 22 perusahaan tidak kesulitan keuangan. Jadi dengan menggunakan model diskriminan pengklasifikasian yang benar adalah sebanyak 25 perusahaan dengan tingkat akurasi $100 \%$, dan pengklasifikasian yang salah tidak ada.

Dari ketiga belas variabel yang digunakan yaitu rasio current asset/current liability (X1), rasio working capital/ total asset (X2), rasio current asset/ total asset (X3), rasio fixed asset/ total asset (X4), rasio sale/ total asset (X5), rasio sale/ current asset (X6), rasio sale/ working capital (X7), rasio net income/ total asset (X8), rasio net income/ equity (X9), rasio liability/total asset (X10), rasio equity/total asset (X11), rasio cash/current liability (X12), rasio cash/ total asset (X13), yang membentuk model diskriminan hanya beberapa variabel saja yaitu rasio working capital/ total asset (X2), rasio current asset/ total asset (X3), dan rasio equity/total asset (X11). Ketiga variabel ini masuk kedalam model dan membentuk model diskriminan untuk memprediksi kesulitan keuangan perusahaan.

Rasio-rasio keuangan yang digunakan dalam memprediksi kesulitan keuangan di tes dengan uji beda dengan menggunakan statistik wilk's lambda dan uji F. ada empat rasio-rasio keuangan yang memenuhi uji statistik wilk's lambda dan uji F. kemudian setelah dilakukan statistik wilk's lambda dan uji F, dilakukan pemilihan variabel untuk membentuk 
model prediksi kesulitan keuangan dengan menggunakaan metode stepwise.

\section{PEMBAHASAN}

Pada hasil penelitian telah dikemukakan beberapa bukti tentang perbedaan rasio keuangan, antara perusahaan yang mengalami kesulitan keuangan maupun yang tidak mengalami kesulitan keuangan dengan menggunakan uji statistik wilks lambda dan uji $F$ sebagai alat ukur. Berdasarkan hasil penelitian tersebut, telah menghasilkan model diskriminan yang dapat dijadikan alat untuk memprediksi kesulitan keuangan pada perusahaan sektor transportasi yang terdaftar di Bursa Efek Indonesia. Kemudian model tersebut perlu di uji lagi dalam kaitannya dengan tingkat keakuratan model tersebut. Dimana pengujian tersebut melalui uji validasi.

\section{SIMPULAN}

Rasio keuangan dapat digunakan untuk membedakan antara perusahan yang mengalami kesulitan keuangan dan perusahaan yang tidak mengalami kesulitan keuangan. Dari hasil pengujian menggunakan analisis diskriminan menunjukkan bahwa rasio yang dapat membedakan antara perusahaan yang mengalami kesulitan keuangan dan perusahaan yang tidak mengalami kesulitan keuangan pada perusahaan sektor transportasi adalah tiga rasio keuangan yaitu, rasio Working Capital/Total Asset, Current Asset/ Total Asset, Equity/Total Asset. Model prediksi kesulitan keuangan pada perusahaan sektor transportasi adalah:

$Z=-4,882+-7,198 \times 2+6,348 \times 3+3,574 X 11$

\section{DAFTAR RUJUKAN}

Altman, Edward, I. 1968. Financial Ratio, Discriminant Analysis and The Prediction of Corporate Bankruptcy. The Journal of Finance (September): 589-609

Altman, Edward, I. 2000. Predicting Financial Distress of Companies:
Revisiting The Z Score adn Zeta ${ }^{\circledR}$ Models.

Al-Rawi, K., R., and Vedd, RR, 2008. The Use of Altman equation for Bankruptcy Prediction in an Industrial Firm, International Business and Economic Research Journal, July

Atmaja, Lukas Setia. 2008. Teori dan Praktik Manajemen Keuangan. Andi. Jakarta

Avianti, Ilya. 2002. Bankruptcy Prediction Models for Companies Listed at the Jakarta Stock Exchange Using Financial Indicators. Economics Journal FE-Unpad

Brealy, Myers dan Marcus. 2008. DasarDasar Manajemen Keuangan Perusahaan. Erlangga. Jakarta

Fachruddin , Khaira Amallia. 2008. Kesulitan Keuangan Perusahaan dan Personal. USU Press Medan

Harahap, Sofyan Syafri. 2011. Analisis Kritis Atas Laporan Keuangan. Raja Grafindo Persada. Jakarta

Kasmir. 2012. Analisis Laporan Keuangan. Rajawali Pers. Jakarta

Peter dan Yoseph. 2011. Analisis Kebangkrutan dengan Metode ZScore Altman, Springate dan Zmijewski pada PT Indofood Sukses Makmur Tbk periode 20052009. Dalam Akurat Jurnal Ilmiah Akuntansi Nomor 04 Tahun ke-2 Januari-April 2011

Santoso, Singgih. 2012. Aplikasi SPSS pada Statistik Multivariat. Elex Media Komputindo. Jakarta

Subramanyan, K.R dan Wild, John J. 2010. Financial Statement Analysis. Salemba empat. Jakarta 
Suharman, H. 2007. Analisis Risiko

Keuangan untuk Memprediksi

Tingkat Kegagalan Usaha Bank. Jurnal Ilmiah ASET, Vol 9, No. 1 Februari

Yuanita, Ika. 2010. Prediksi Financial Distress dalam Industri Tekstil dan Garmen (Bukti Empiris di Bursa Efek Indonesia. Dalam Jurnal Akuntansi \& Manajemen Vol. 5 No.

1 Hal 101-119 